\title{
The Mediating Effect of Cognitive and Emotional Satisfaction on Customer Loyalty
}

\author{
Maznah Wan Omar \\ Universiti Teknologi MARA Kedah \\ Peti Surat 187, 08400 Merbok, Kedah, Malaysia \\ maznah199@kedah.uitm.edu.my
}

\begin{abstract}
Loyal customers are among the greatest revenue producer and are more likely to occur in a form of word-of-mouth. In the compound and vibrant Malaysian home computer retail market today, customer loyalty through word-of-mouth marketing tends to occur very slowly and is limited geographically but is a very potent method of marketing. The influence of cognitive and emotional satisfaction on the relationship between salesperson presentation skills and customer's loyalty through intention to promote by word-of-mouth is vital. This will then lead to increased benefits for the organization in the form of customer loyalty. The cognitive evaluation of customer satisfaction was found to explain customer loyalty in a retail setting more than the emotional reaction. This finding holds importance to those retailers who have been able to generate high expectations in the eyes of their customers.
\end{abstract}

Keywords: Adaptive selling skills, sales presentation skills, Customer satisfaction, Customer loyalty

\section{INTRODUCTION}

As competition deepens, products and services become more indistinguishable, and markets become established, it is becoming increasingly tougher for companies in retailing industries to distinguish themselves from other stores. Simply offering customers with technical solutions to problems does not be sufficient anymore to be competitive and obtain and retain market share. Various value-added services, which commence before the actual operation begins, had gone far beyond it, so as to stay competitive and develop customer loyalty. Research and business customs have shown that upholding customers through value-added services costs less than obtaining new ones (Wetzels et al., 1998).

A prevailing belief holds that an essential key to performance rests with the ability to sustain 
customer relationships (Anderson et al., 1994). Correspondingly, as relational value continues beyond price, customer bond are particularly effective when involved in long-term relationships (Wood, 1995).

\section{LITERATURE REVIEW}

\section{Salesperson Behavior Performance}

In recent years, a number of authors have been confronted with this issue of the changing role of the sales force. Up-and-coming trends of the extent and scope recorded above require a re-evaluation of the activities that salespeople must execute in order to successfully build and manage customer loyalty. Marshall et al., (1999), interviewed a diversity of professional salespeople to give evidence for 49 new sales activities that were not pointed out in Moncrief's (1986) original list. These latest activities fall into the following main categories: communication technology, selling technology, activities related to adaptive and consultative selling, and team-oriented activities. Many of the specific activities within these categories involve skills and content knowledge dissimilar from those traditionally observed in the past as key salesperson success factors.

This study therefore will consider how cognitive and emotional satisfaction mediates the relationship between salesperson presentation skills and customer's intention to word-of-mouth. These situational factors have not been considered in prior research and provide new avenues for examining salesperson presentation skills in Malaysian market and its consequences. Additionally, as most studies have considered salespeople as their unit of analysis, this study will add to the small but imminent body of research that investigates performance and effectiveness relationships at the customer's level.

\section{Formation of loyalty through satisfaction}

It is by and large believed that satisfaction leads to repeat purchase and positive word-of-mouth recommendation, which are the main indicators of loyalty. Marketing literature has paid much attention to the relationship between customer satisfaction and loyalty (Chi, 2005). A number of studies have confirmed a significant positive relationship between customer satisfaction and loyalty/retention (Chi, 2005). If consumers are satisfied with the product or service, they are more likely to carry on purchasing, and are more willing to spread positive WOM.

\section{Salesperson presentation skills}

Churchill et al., (1997, p. 367) define selling skill as a salesperson's "learned proficiencies at performing job activities," and describe Salesperson presentation skills as the skills that are associated to successfully conducting the personal selling process (i.e. the series of interconnected steps that salespeople generally use to link with the influence customer). 
Recognizing the importance of salesperson presentation skills, Marshall et al. (2003) gathered and ranked sales manager perceptions of "success factors" that contribute to salesperson job performance. They report that managers feel that six specific salesperson presentation skills: listening, adaptive selling, handling objections, closing, negotiating, and prospecting (in descending order of perceived importance) are highly important to salesperson performance (Johlke, 2006). Accordingly, this group of salesperson presentation skills will be used at the heart of the hypothesized model.

\section{Customer satisfaction}

The importance of customer satisfaction to the success of consumer goods manufacturers (Burns \& Neisner, 2006) and to the success of retailers (Darian et al., 2001) has been well documented. Customer satisfaction is regarded as a primary determining factor of repeat shopping and purchasing behavior. The greater the degree to which a consumer experiences satisfaction with a retailer, for instance, the greater the probability the consumer will revisit the retailer (Burns \& Neisner, 2006, p. 49; Wong \& Sohal, 2003).

In summary, we note the distinction between transaction-specific and overall satisfaction, and for this study, we adopt the broader definition of satisfaction whereby the overall measure is an aggregation of all previous transaction-specific satisfaction, and involves both cognitive and affective components. Recently, the overall measure has been shown to be a better predictor of repurchase intentions (Jones \& Suh, 2000).

\section{Research Framework and Hypotheses}

Based on the review of literatures concerning the study variables on salesperson presentation skills, customer satisfaction, and customer's intention to word-of-mouth, the theoretical framework for this study was developed based on Oliver's (1997, p. 392) Cognitive-Affective-Conative Behavior pattern model. This research model has been adapted and used in this study.

\section{Relationship between Salesperson presentation skill and Intention to WOM}

Although a customer's personality and the employee's customer orientation were considered an important antecedent to relationship strength, salesperson presentation skill rather than his/her personality would perform a greater part in determining relationship strength (Foster \& Cadogen, 2000). Salespersons are social actors who learn behaviors that are appropriate to the positions they take up (Bove \& Johnson, 2000). In other words, salesperson can be motivated to adapt their behavior to situational requirements in spite of personal preferences (Bove \& Johnson, 2000).

To date, there is a lack of studies investigating the numerous aspects of service that are imperative to customer retention (Zeithaml, 2000)? Furthermore, the different outcomes (i.e. 
attitudinal and behavioral) of relationship strength are left predominantly unexplored in the relationship marketing literature. In addition, there is a lack of studies that explore the impact of factors such as salesperson presentation skill on customer's intention to WOM. Conclusively, there is little empirical work investigating customer relationship economies, which is the link between attitudinal measures (i.e. salesperson presentation skill, customer satisfaction) and behavioral measures (i.e. customer loyalty, intention to repurchase, intention to WOM, and long-term customer relationship profitability), Wong and Sohal, (2006). Therefore, in line with the above reasoning's and findings, it is conjectured that:

\section{H1: There is a direct positive relationship between salesperson's presentation} skills and intention to word-of-mouth (WOM).

\section{Relationship between Customer satisfaction and customer's intention to WOM}

Customer satisfaction is important to marketers because it is usually assumed to be a significant determinant of recurring sales, positive word-of-mouth, intention to repurchase, and customer loyalty. It is worthy to consumers because it reflects a positive outcome following the outlay of limited resources and/or the positive accomplishment of prior needs. As a consequence, maximizing satisfaction is seen as a significant objective, collectively for both the firm and the consumer (Mouri, 2005).

Likewise, theory suggests that satisfaction feeds back into the system to influence ensuing intentions and behaviors (Wallace et al., 2004). Customer's satisfaction with the shopping experience should reflect well on the retailer. An increase in satisfaction has been shown to result in increased customer loyalty (Donio et al., 2006). From the above arguments it is hypothesized that:

H2: There is a direct positive relationship between customer satisfaction and intention to word-of-mouth.

H2a: There is a direct positive relationship between cognitive satisfaction and intention to word-of-mouth.

H2b: There is a direct positive relationship between emotional satisfaction and intention to word-of-mouth.

\section{The mediating effect of Customer Satisfaction on Salesperson presentation skill and Customer's intention to WOM relationship.}

Overall satisfaction with an experience does lead to customer loyalty (Caruana, 2002). Bearden and Teel (1983) argue that customer satisfaction is imperative to the marketer because "it is generally assumed to be significant determinant of repeat sales, positive word of mouth, intention to repurchase, and consumer loyalty". Similarly, Bloemer and Poiesz (1989) have also argued that "satisfaction can be thought of as an important determinant of customer loyalty", while Selnes (1993) argues that it is satisfaction with a brand or service that leads to 
customer loyalty. This view is also supported by Dick and Basu (1994). LaBarbera and Mazursky (1983) show empirically that brand and service loyal customers had a lower probability to substitute brands or service due to higher levels of satisfaction. On the basis of the above findings, customer satisfaction is indicated as having a function and acting as a mediator in the link between salesperson presentation skills and customer loyalty (Lim, 2004). Therefore, in line with the above reasoning's and findings, the following were hypothesized:

H3: Customer satisfaction mediates the relationship between salesperson presentation skills and intention to word-of-mouth.

H3a: Cognitive satisfaction mediates the relationship between salesperson presentation skills and intention to word-of-mouth.

H3b: Emotional satisfaction mediates the relationship between salesperson presentation skills and intention to word-of-mouth.

\section{METHODOLOGY}

\section{Sampling Design}

To have a representative finding, the sampling technique used must be objective. This is an important effort adopted by most researchers in order to furnish a finding pertinent to the general. To choose the sample for this study, probability random sampling was used. A probability sample is necessary if the sample is to be representative of the population (Reeves, 1992). Therefore, a two-stage systematic sampling technique is employed in this study.

\section{Population and sample size}

In determining the sample size for this study, sample size selected was based on the criteria set according to Sawyer and Ball (1981). According to Sawyer and Ball (1981), it is estimated that a proportion of $13 \%$ of the explained variance to effect size values is a medium effect size for regression analysis. One common measure of effect size is eta squared. Eta squared represents the proportion of variance of the dependent variable that is explained by the independent variable (Pallant, 2005).According to Cohen (1988), the strength of the effect size are interpreted as follows; $0.01=$ small effect size, $0.06=$ moderate effect size, and $0.14=$ large effect size. Thus five independent variables were used and using the statistical significance of 0.05 (95\% confidence level) and an effect size values of .13 is found to be truly sufficient and not by chance.

\section{Goodness of Measure}

In determining the goodness of data for the study, factor analysis and reliability analysis were performed. Factor analysis was used to assess the convergent validity of the items used in the 
questionnaire while Cronbach's alpha was performed to examine the internal consistency of the factors obtained. The result of the reliability test are presented in Table 1

Table 1. Reliability Coefficients for the Variables in the Study

\begin{tabular}{lcccc}
\hline \multicolumn{1}{c}{ Construct/Variables } & $\begin{array}{c}\text { Number } \\
\text { of Items }\end{array}$ & $\begin{array}{c}\text { Cronbach's } \\
\text { Alpha }\end{array}$ & Mean & Std. Dev \\
\hline Sales Presentation skill/Knowledge & 3 & .75 & 3.78 & 0.72 \\
\hline $\begin{array}{l}\text { Customer satisfaction } \\
\text { Emotional Satisfaction }\end{array}$ & 4 & .84 & 4.10 & 0.64 \\
\hline Cognitive Satisfaction & 4 & .76 & 3.85 & 0.58 \\
\hline $\begin{array}{l}\text { Customer loyalty } \\
\text { Word-of-mouth (WOM) }\end{array}$ & 2 & .69 & 3.93 & 0.59 \\
\hline Note: All items used a 5-point Likert scale (1 = strongly disagree and 5 = strongly agree)
\end{tabular}

The result of the reliability analysis sum up in Table 1 confirmed that all the scales shown, reveal a high internal consistency and reliability with Cronbach's alpha values higher than the minimum perimeter, (Cronbach's alpha $>0.60)$.

\section{Research Findings and Discussion Hypotheses Testing}

Multiple regression tests were conducted in order to test the relationship between the predictor variable and the criterion variable. Respondents' demographic variables such as salesperson are younger or older than the customers, gender, and ethnicity were statistically controlled (Connel et al., 2003; Hemdi, 2006). Hence, these variables were entered into the regression equation in the first step. The predictor variables were entered in the second step. The following Table's below summarizes the result of the analyses.

\section{Regression Analysis with Control Variables}

The relationship between salesperson presentation skills and intention to word-of-mouth

Table 2. Results of hierarchical regression analysis of salesperson presentation skills on intention to word-of-mouth

\begin{tabular}{lcc}
\hline Predictors & Model 1 & Model 2 \\
\hline & Std. $\beta$ & Std. $\beta$ \\
\hline Step 1: Control Variables & & \\
Younger or older & -.05 & .01 \\
Gender & -.01 & -.01 \\
Ethnicity & .09 & -.02 \\
\hline
\end{tabular}




\section{Step 2:}

Sales presentation skills

$$
\mathrm{R}^{2}
$$

Adj. $\mathrm{R}^{2}$

$\mathrm{R}^{2}$ Change

F-Change

Note. Significant levels: ${ }^{*} \mathrm{p}<0.05, * * \mathrm{p}<0.01$

.43

.42

$68.19 * *$

From Table 3 above, salesperson presentation skills have positive and significant association with intention to word-of-mouth; salesperson presentation skills $(\beta=.16, p<.01)$, and thus, the results provide evidence that hypotheses $\mathrm{H} 1$ is fully supported.

\section{The Relationship between Customer Satisfaction and Intention to WOM}

To test for hypothesis 2a, another set of regression analysis was performed. The purpose of this analysis is to test for the effect of cognitive satisfaction on intention to word-of-mouth. The predictor variable was cognitive satisfaction. The criterion variables relates to intention to word-of-mouth. Salesperson's demographic variables such as younger or older than the customers, gender, and ethnicity were statistically controlled. Hence, these variables were entered into the regression equation in the first step. Cognitive satisfaction was entered in the second step. Table 3 summarizes the results of the hierarchical regression analysis. These results provide evidence that hypothesis $\mathrm{H} 2 \mathrm{a}$ is accepted.

Table 3. Results of hierarchical regression analysis of cognitive satisfaction on Intention to word-of-mouth

\begin{tabular}{lcc}
\hline Predictors & Model 1 & Model 2 \\
\hline & Std. $\beta$ & Std. $\beta$ \\
\hline Step 1: Control Variables & & \\
Younger or older & -.05 & -.04 \\
Gender & -.01 & -.02 \\
Ethnicity & .06 & .02
\end{tabular}

Step 2:

Cognitive satisfaction

\begin{tabular}{lcc}
$\mathrm{R}^{2}$ & .01 & .41 \\
Adj. $\mathrm{R}^{2}$ & -.00 & .40 \\
$\mathrm{R}^{2}$ Change & .01 & .40 \\
F-Change & .70 & $303.91^{* *}$ \\
\hline
\end{tabular}

Note. Significant levels: ${ }^{*} \mathrm{p}<0.05, * * \mathrm{p}<0.01$

Additionally, to test for hypothesis $2 \mathrm{~b}$, another set of regression analysis was also performed. 


\section{Macrothink}

International Journal of Management Innovation Systems ISSN 1943-1384

2009, Vol. 1, No. 2: E5

The purpose of this analysis is to test for the effect of emotional satisfaction on intention to word-of-mouth. The predictor variable was emotional satisfaction. The criterion variables relates to intention to word-of-mouth. Salesperson's demographic variables such as younger or older than the customers, gender, and ethnicity were statistically controlled. Hence, these variables were entered into the regression equation in the first step. Emotional satisfaction was entered in the second step. Table 4 summarizes the results of the hierarchical regression analysis. These results provide evidence that hypothesis $\mathrm{H} 2 \mathrm{~b}$ is accepted.

Table 4. Results of hierarchical regression analysis of emotional satisfaction on Intention to word-of-mouth

\begin{tabular}{lcc}
\hline Predictors & Model 1 & Model 2 \\
\hline & Std. $\beta$ & Std. $\beta$ \\
\hline Step 1: Control Variables & & \\
Younger or older & -.05 & .01 \\
Gender & -.01 & -.02 \\
Ethnicity & .12 & .10 \\
& & \\
Step 2: & & $.54^{* *}$ \\
Emotional satisfaction & & .30 \\
\hline $\mathrm{R}^{2}$ & .01 & .29 \\
Adj. R & .00 & .29 \\
$\mathrm{R}^{2}$ Change & .01 & $188.57^{* *}$ \\
F-Change & 1.10 & \\
\hline
\end{tabular}

Note. Significant levels: ${ }^{*} \mathrm{p}<0.05,{ }^{*} \mathrm{p}<0.01$

The Mediating Effect of Cognitive Satisfaction on the Relationship between Salesperson Presentations Skills and Intention to Word-Of-Mouth

Hypothesis 3 a posits that cognitive satisfaction mediates the relationship between salesperson presentation skills and intention to word-of-mouth. Results in Table 4 shows that none of the control variables had significant influence on intention to word-of-mouth in step 1, however, salesperson presentation skills $(\beta=.25, \mathrm{p}<.01)$, were found to significantly influenced intention to word-of-mouth in the second regression equation.

Additionally, the third regression equation resulted in sales presentation skill to be insignificant after the third regression. Thus it indicates that cognitive satisfaction fully mediates the relationship between sales presentation skills on intention to word-of-mouth. The comparison can be seen in Table 5. These results provide evidence that hypothesis H3a is supported.

Table 5. Summary of mediating Effects of Cognitive Satisfaction on the Relationship between Salesperson presentation skills and intention to word-of-mouth

\section{Criterion Variables}




\begin{tabular}{|c|c|c|c|c|c|}
\hline \multirow[t]{2}{*}{ Predictors } & \multicolumn{2}{|c|}{$\begin{array}{c}\text { Significant } \\
\text { Levels and Beta } \\
\text { before } \\
\text { Mediating } \\
\text { (Regression } \\
\text { Equation II - } \\
\text { DV on IV) }\end{array}$} & \multicolumn{2}{|c|}{$\begin{array}{l}\text { Significant Levels } \\
\text { and Beta after } \\
\text { Mediating } \\
\text { (Regression } \\
\text { Equation III - DV } \\
\text { on IV \& MV) }\end{array}$} & \multirow[t]{2}{*}{ Results } \\
\hline & Step 1 & Step 2 & Step 1 & Step 2 & \\
\hline \multicolumn{6}{|l|}{ Control } \\
\hline Younger or older & -.05 & .02 & -.05 & -.00 & \\
\hline Gender & .00 & .00 & -.01 & -.01 & \\
\hline ethnicity & .10 & -.01 & .06 & .01 & \\
\hline \multicolumn{6}{|l|}{ Independent } \\
\hline $\begin{array}{l}\text { Salesperson } \\
\text { presentation skills }\end{array}$ & & $.25 * *$ & & .07 & Full mediation \\
\hline \multicolumn{6}{|l|}{ Mediating } \\
\hline Cognitive satisfaction & & & & $.31 * *$ & \\
\hline $\mathrm{R}^{2}$ & .01 & .43 & .01 & .49 & \\
\hline Adj. $R^{2}$ & .00 & .42 & -.00 & .48 & \\
\hline $\mathrm{R}^{2}$ Change & .01 & .42 & .01 & .49 & \\
\hline F change & 1.09 & $68.19 * *$ & .70 & $70.39 * *$ & \\
\hline
\end{tabular}

Note. Significant levels: ${ }^{*} \mathrm{p}<0.05,{ }^{* *} \mathrm{p}<0.01$

The Mediating Effect of Emotional Satisfaction on the Relationship between Salesperson Presentations Skills and Intention to Word-Of-Mouth

Hypothesis $3 \mathrm{~b}$ posits that emotional satisfaction mediates the relationship between salesperson presentation skills and intention to word-of-mouth. Results in Table 6 shows that none of the control variables had significant influence on intention to word-of-mouth in step 1 , however, salesperson presentation skills $(\beta=.18, \mathrm{p}<.01)$, were found to significantly influenced intention to word-of-mouth in the second regression equation.

Subsequently, the sales presentation skill was found to be significant after the third regression. Thus it indicates that emotional satisfaction partially mediates the relationship between sales presentation skills on intention to word-of-mouth. The comparison can be seen in Table 6 . These results provide evidence that hypothesis $\mathrm{H} 3 \mathrm{~b}$ is partially supported.

Table 6. Summary of mediating Effects of Emotional Satisfaction on the Relationship between Salesperson presentation skills and intention to word-of-mouth 


\begin{tabular}{|c|c|c|c|c|c|}
\hline \multirow{3}{*}{ Predictors } & \multicolumn{4}{|c|}{ Criterion Variables } & \multirow{3}{*}{ Results } \\
\hline & \multicolumn{2}{|c|}{$\begin{array}{c}\text { Significant Levels } \\
\text { and Beta before } \\
\text { Mediating } \\
\text { (Regression } \\
\text { Equation II - DV } \\
\text { on IV) }\end{array}$} & \multicolumn{2}{|c|}{$\begin{array}{l}\text { Significant Levels } \\
\text { and Beta after } \\
\text { Mediating } \\
\text { (Regression } \\
\text { Equation III - DV } \\
\text { on IV \& MV) }\end{array}$} & \\
\hline & Step 1 & Step 2 & Step 1 & Step 2 & \\
\hline \multicolumn{6}{|l|}{ Control } \\
\hline Younger or older & -.05 & .05 & -.05 & .01 & \\
\hline Gender & .00 & .00 & -.01 & -.01 & \\
\hline ethnicity & .10 & -.01 & .06 & .02 & \\
\hline \multicolumn{6}{|l|}{ Independent } \\
\hline $\begin{array}{l}\text { Sales person } \\
\text { presentation skills }\end{array}$ & & $.18^{* *}$ & & $.16^{* *}$ & $\begin{array}{l}\text { Partial } \\
\text { mediation }\end{array}$ \\
\hline \multicolumn{6}{|l|}{ Mediating } \\
\hline Cognitive satisfaction & & & & $.20 * *$ & \\
\hline $\mathrm{R}^{2}$ & .01 & .43 & .01 & .48 & \\
\hline Adj. $R^{2}$ & .00 & .42 & -.00 & .47 & \\
\hline $\mathrm{R}^{2}$ Change & .01 & .42 & .01 & .47 & \\
\hline F change & 1.09 & $68.19 * *$ & .70 & $65.45 * *$ & \\
\hline
\end{tabular}

Note. Significant levels: $* \mathrm{p}<0.05, * * \mathrm{p}<0.01$

\section{DISCUSSION}

Hypothesis 3 deals with the mediating role of customer satisfaction in the relationship between salesperson presentation skills and intention to word-of-mouth.

Results of this study found that cognitive satisfaction partially mediates the relationship between sales presentation skills on intention to word-of-mouth. This implied that sales presentation skills have an indirect impact on customer's intention to word-of-mouth via cognitive satisfaction. This result suggests that salesperson who poses an overall sales presentation skill, plus an ability to apply these skills during their interaction with the customers is vital in enhancing customer's intention to word-of-mouth.

The result of this study is consistent with the findings of previous study by Shemwell et al., (1998, p. 158) which suggest that satisfaction is a more central construct which mediates the effect of service quality perceptions on behavioral intentions and other outcomes. The published research in the field of service marketing universally acknowledges a strong positive correlation between salesperson service quality and satisfaction, some early works depicted salesperson service is perceived as an antecedent of satisfaction (Anderson \& Sullivan, 1993; Oliver, 1993). 
Thus the results of this study suggest that efforts to increase customer's loyalty should focus on enhancing customer's cognitive satisfaction during the salesperson/customers interaction. Special attention should be given to the enhancement of sales presentation skills, which were found to have significant effects on customer's intention to word-of-mouth.

\section{Limitations and Future Research}

Future research may benefit if some limitations of this study are noticed. Although we have examined a number of important issues in this study, there are several limitations inherent in the study. Firstly, only computer retailers in the northern states of Malaysia were examined. As a consequence, and regardless of the fact that the customers of the firm represent a wide range of industries, the generalization of the findings to other retail organizations is limited. However, as noted by Foster and Cadogen (2000), the generalization of studies undertaken in a single firm must be viewed with some skepticism; the results are likely to have increased internal validity. Clearly future research which provides more information on the external validity of our study would be most welcome.

\section{CONCLUSION}

The present study confirms that cognitive satisfaction was able to explain customer's intention to word-of-mouth in a retail setting in the Malaysian market. The finding suggest that computer retailers whose customers poses high expectations on the salesperson's sales presentation skills may need to place explicit attention on their customers' cognitive evaluations since their customers' cognitive reactions to performance appear to contribute to their assessments of satisfaction.

Finding in this study shows that, loyalty defined by personal positive experience (i.e., affective loyalty), is most associated with word-of-mouth. Because person-to-person communication is touted as "one of the most powerful types of media", and affective loyalty is the largest correlate to word-of-mouth, therefore, successful business strategies will have to include creating situations where emotional attachments to services provided by the salesperson are developed. Consumers who believe in the salespersons or are involved in the purchase process tend to participate in word-of-mouth because it enhances commitment to their own attitude.

\section{REFERENCES}

Anderson, E. W., Fornell, C., \& Lehmann, D.R. (1994). Customer satisfaction, market share, and profitability: findings from Sweden. Journal of Marketing, 58 (July), 53- 66.

Anderson, E.W. \& Sullivan, M.W.(1993). The antecedents and consequences of customer satisfaction for firms. Marketing Science, 12, 125-143. 
Bearden, W.O. \& Teel, J.E. (1983). Selected determinants of consumer satisfaction and complaint behavior. Journal of Marketing Research, 20, 21-8.

Bloemer, J.M.M., \& Poiesz, T.B.C. (1989). The illusion pf consumer satisfaction. Journal of Consumer Satisfaction, Dissatisfaction and Complaining Behavior, (2), 43-8.

Bove, L.L., \& Johnson, L.W. (2000). A customer-service worker relationship model. International Journal of Service Industry Management, 11(5), 491-511.

Burns, D.J., \& Neisner, 1. (2006). Customer satisfaction in a retail setting: The contribution of emotion. International Journal of Retail \& Distribution Management, 34(1), 49-66.

Caruana, A. (2002). Service Loyalty: The effects of service quality and the mediating role of customer satisfaction. European Journal of Marketing, 36, 811-1352.

Chi, G. (2005). A Study of Developing Destination Loyalty Model. Doctor of Philosophy Dissertation, Oklahoma State University. (UMI No. 3181663).

Churchill, G., Ford, N., \& Walker, O. (1997). Sales force management. Richard D. Irwin, Chicago, IL.

Cohen, J.W.(1988). Statistical power analysis for the behavioral science. Hillsdale, NJ: Lawrence Erlbaum Associates.

Connell, J., Ferres, N., \& Travaglione, T. (2003). Engendering trust in managersubordinate relationships; Predictors and outcomes. Personnel Review, 32(5), 569-587.

Darian, J.C., Tucci, L.A., \& Wiman, A.R. (2001). Perceived salesperson service attributes and retail patronage intentions. International Journal of Retail \& Distribution Management, 29, 4(5), 205-213.

Dick, A.S., \& Basu, K. (1994). Customer loyalty: Toward an Integrated Conceptual Framework. Journal of the Academy of Marketing Science, 22 (winter), 99-113.

Donio' J., Massari, P., \& Passiante, G. (2006). Customer satisfaction and loyalty in a digital environment: An empirical test. Journal of Consumer Marketing, 23(70), 445-457.

Foster, B.D., \& Cadogan, J.W. (2000). Relationship selling and customer loyalty: an empirical investigation. Marketing Intelligence \& Planning, 18(4), 185-199.

Hemdi, M. A. (2006). Turnover Intentions of Hotel Employees: The Role of Human

Resource Management Practices, Trust in Organization, and Affective Commitment.

Phd Thesis, Universiti Sains Malaysia.

Johlke, M.C. (2006). Sales presentation skills and salesperson job performance. Journal of Business \& Industrial Marketing, 21(5), 311-319.

Jones, M. A. \& Suh, J. (2000). Transaction-specific satisfaction and overall satisfaction: an empirical analysis. Journal of Services Marketing, 14(2), 147-159.

LaBarbera, P.A., \& Mazursky, D. (1983). A longitudinal assessment of consumer satisfaction/dissatisfaction: the dynamic aspect of the cognitive process. Journal of Marketing Research, 20(11), 393-404.

Lim, E.H. (2004). Perception of service quality, value, and satisfaction in determining customer loyalty: A study in 5-star hotels in Penang, MBA Dissertation, Universiti Sains Malaysia.

Marshall, G.W., Goebel, D.J., \& Moncrief, W.C. (2003). Hiring for success at the buyer seller interface. Journal of Business Research, 56, 247-255.

Marshall, G.W., Moncrief, W.C., \& Lassk, F.J. (1999). The current state of sales forces 
activities. Industrial Marketing Management, 28 (January), 87-98.

Moncrief, W.C. (1986). Selling activity and sales position taxonomies for industrial sales forces. Journal of Marketing Research, 23(August), 261-70.

Mouri, N. (2005). A Consumer-Based Assessment of Alliance Performance: An Examination of Consumer Value, Satisfaction and Post-Purchase Behavior. Doctor of Philosophy Dissertation, University of Central Florida, USA. (UMI No. 3193496).

Oliver, R.L. (1997). Satisfaction: A Behavioral Perspective on the Consumer. New York: The McGraw-Hill Companies, Inc.

Oliver, R.L.(1993). A conceptual model of service quality and service satisfaction: compatible goals, different concepts, Advances in Services marketing and Management. 2, JAI Press, 65-85.

Pallant, J. (2005). SPSS Survival Manual: A step by step guide to data analysis using SPSS for Windows (Version 12). Open University Press; 2Rev Ed edition.

Reeves, C.C. (1992). Quantitative research for the behavior sciences. New York, NY: John Wiley \& Sons, Inc.

Sawyer, A. G., \& Ball, A. D. (1981). Statistical Power and Effect Size in Marketing Research. Journal of Marketing Research, 275-290.

Selnes, F. (1993). An examination of the effect of product performance on brand reputation, satisfaction and loyalty. European Journal of Marketing, 27(9), 19-35.

Shemwell, D.J., Yavas, U., \& Bilgin. Z. (1998). Customer-service provider relationships: an empirical test of a model of service quality, satisfaction and relationshiporiented outcomes. International Journal of Service Industry Management, 9(2), 155-168.

Wallace, D.W., Giese, J.L., \& Johnson, J. L. (2004). Customer retailer loyalty in the context of multiple channel strategies. Journal of Retailing, 80, 249-263.

Wetzels, M., Ruyter, K. d., \& Birgelen, M.V. (1998). Marketing service relationships: the role of commitment. Journal of Business \& Industrial Marketing, 13(4/5), 406-423.

Wong, A., \& Sohal, A.S. (2006). Understanding the quality of relationships in consumer services: A study in a retail environment. International Journal of Quality \& Reliability Management, 23(3), 244-264.

Wong, A., \& Sohal, A. (2003). Assessing customer-salesperson interactions in a retail chain: differences between city and country retail district. Marketing Intelligence \& Planning, 21(5), 292-304.

Wood, M.F. (1995). Get more for your product or service: develop value added buyers. American Salesman, 40(April), 3-7.

Zeithaml, V.A. (2000). Service quality, profitability and the economic worth of customers: what we know and what we need to learn. Journal of the Academy of Marketing Science, 28(1), 67-85. 